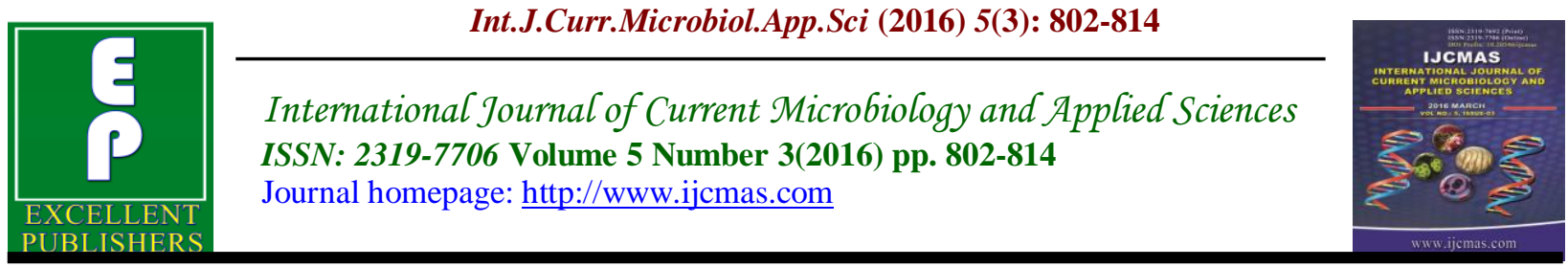

Original Research Article

http://dx.doi.org/10.20546/ijcmas.2016.503.093

\title{
Aphrodisiac Properties of Hypocotyls Extracts of Borassus aethiopum Mart (Arecaceae) Collected in Central of Benin Republic
}

\author{
Florence Gbesso ${ }^{1}$, Arlette Adjatin ${ }^{2}$, Alexandre A. Dansi ${ }^{2}$ and \\ Akpovi Akoegninou ${ }^{3}$
}

${ }^{1}$ Laboratory of Biogeography and Environmental Expertise (LaBEE), Faculty of Letter, Arts and Human Sciences, University of Abomey-Calavi (UAC), BP 677 Abomey-Calavi, Benin

${ }^{2}$ Laboratory of Biotechnology, Genetic Resources and Plant and Animal Breeding

(BIORAVE), Faculty of Sciences and Technology of Dassa,

Polytechnic University of Abomey (UPA), 01 BP 14 Dassa-Zoumè

${ }^{3}$ National Herbarium, Department of Botany and Plant Biology, Faculty of Sciences and

Technology (FAST), University of Abomey-Calavi (UAC), 01 BP 526 Cotonou, Benin

*Corresponding author

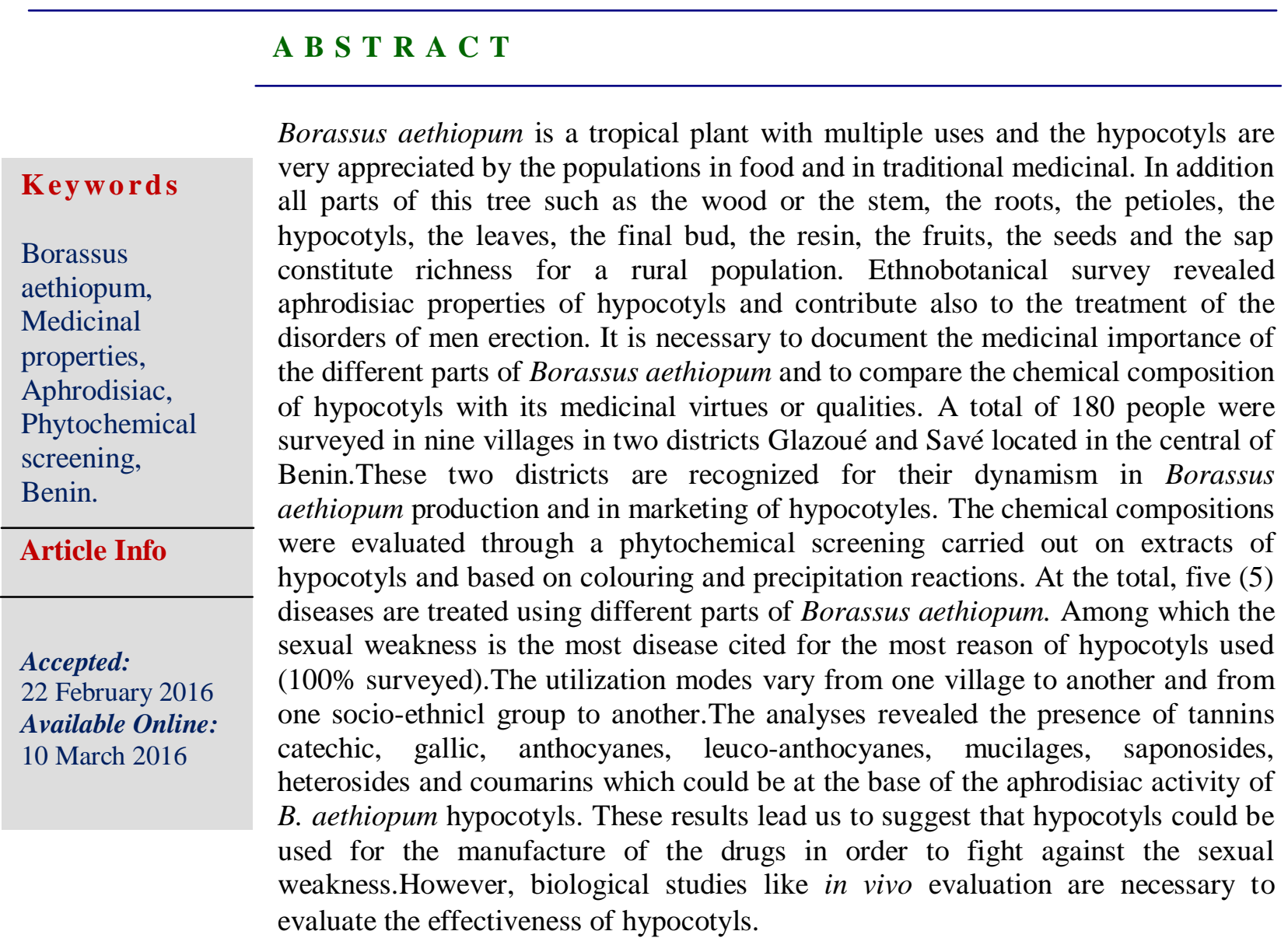




\section{Introduction}

The use of the medicinal plants in the treatment of pathologies dated to several millions of years (Adjanohoun, 1995; WHO, 2002). The traditional medicinal always constituted for the rural populations the principal sources for health. Across the world, more than $80 \%$ of the population used medicinal plants for primary health (Sandhya et al., 2006; Visweswari et al., 2013; Ahouansikpo et al., 2016).The plants in general produce primary metabolites which are implied in the cellular metabolism but also secondary metabolites which are chemically activate compounds. The secondary compounds confer to the plants many medicinal properties at the base of their use by the populations (Zwenger and Basu, 2008; Visweswari et al., 2013; Adjatin et al., 2013). In Benin republic, Borassus aethiopum, is part of many plant and under-utilized species which the different part have many usage such as food, economic medicinal and pharmaceutic (Kansolé, 2010; Gbesso et al., 2013).

The pulp, the seeds, the hypocotyls and the sap are used in various ways for human consumption. Several authors have been reported and summarized the food and medicinal utilization of Borassus aethiopum (Akinniyi et al., 2000; Gbesso et al., 2013). The different parts of $B$. aethiopum such as wood, the roots, the petioles, the leaves, the final bud, the resin, the fruits, the seeds and the sap constitute a richness for rural population and also significant source of income generation for the rural communities especially for women (Wasiri et al., 2010; Gbesso et al., 2013). B. aethiopum fruits are rich in glucides, calcium, proteins and vitamins C, B1, B2, PP (Kodjo, 2005).In Côte d'Ivoire Borassus aethiopum is required for his sap which is used to manufacture vinegar, sugar and drug
(Yaméogo, 2007).The powder combination of male inflorescences of Borassus aethiopum with shea butter is used like antifongic for the cutaneous lesion. The male inflorescences have diuretic properties, and are also used in the treatment of the sexually transmitted diseases and the viral infections. Former studies revealed the antiinflammatory drug activity, antipyretic of the extracts of this plant (Sakande et al., 2004). Hypocotyls flour with high value contents of lipids, starch, minerals and fiber and also couscous have been developed in Benin, (Azokpotaet al, 2012) and in Cameroun (Ali et al, 2010);Also, The physicochemical properties of starch of $B$ aethiopicum might be suitable for uses ace a dilute, binder and disintegrant (Odeku and Itiola, 2007; Adamu et al., 2012). In Northern Benin, the young germinating shot of the seedling is consumed and play great role in food crisis and use it as aphrodisiac purpose (Akinniyi et al., 2000). In a traditional way, the hypocotyls of this plant are used for the treatment of several diseases included sexual weakness (Adjou, 2006; Gbesso et al., 2013) which is considered as social handicap and a problem of public health (Bonetti, 2007;Békro et al., 2007). Moreover, this physiological issue is often associated with some chronic pathologies such as diabetes, neuropathy, depression, etc. (Boua, 2005). Borassus aethiopum could be a significant source for the research and for some firms to develop somebio actives molecules to solve this disease as the case of the example of others plants which constitute resources for pharmaceutical industry (Awono et al., 2009).Unfortunately, in Benin there is no major work on $B$. aethiopum to documentation aphrodisiac property of the hypocotyls. This study was initiated to document the medicinal knowledge of the rural communities on the hypocotyls and to identify the phytochemical elements conferring on this 
species the aphrodisiacs properties.

\section{Materials and Methods}

\section{Presentation of the zone of study}

The study was conducted in Central Benin precisely in two districts Savè and Glazoué where the species is rather abundant and is important for income generating (Gbesso et al., 2012). These two districts are located between the parallels 730' and 830' of Northern latitude and between the meridian lines 205' and 246' of longitude(Figure 1).Climate in this area is subequatorial with two rains seasons and two dry seasons (Akoegninou et al., (2006). According to the national statistic, the population of these two districts is estimated to 210.921 peoples and in the majority inhabited by Tchabè, Idaasha and Mahi ethnic groups (RGPH4, 2013).

In each district, the choice of the villages was done base on two fundamental criteria such as the presence of high groups sociolinguistic and also the exploitation of the species.Considering these two different criteria, nine (9) villages were selected in the two districts (Table 1, Figure1) and in each village, 20 households were surveyed make a total of 180 households surveyed in the study area (Table 1).

\section{Ethnobotanical Data Collecting and Data Analysis}

Data were collected during expeditions from the different sites through the application of participatory research appraisal tools and techniques, such as direct observation, group discussions, individual interviews, and field visits using a questionnaire (Adjatin et al., 2012). In each village, interviews were conducted with the help of a local translator. Group discussions were held with both females, males of different ages. In each site, local the forest keepers, agentsand the chiefs of the village were involved in the study to facilitate the organization of the meetings and data collection. The medicinal importance of Borassus aethiopum was then given during ethnobotanical survey. The collected data were related to the knowledge relating to the medicinal properties, the medico-magic usage, the different parts of the tree used and the forms of usage.

The different results were analysed through descriptive statistical as frequency compute, mean and the results were presented as figures and tables.

Table.1 List of the Different Surveyed Villages in the Two Districts in Central Benin

\begin{tabular}{llllc}
\hline Serial number & Villages & Districts & Socio-ethnic group & Number of survey \\
\hline 1 & Akon & Savè & Tchabè & 20 \\
2 & Boubou & Savè & Tchabè & 20 \\
3 & Diho & Savè & Tchabè/Idaatcha & 20 \\
4 & Djabata & Savè & Tchabè & 20 \\
5 & Hoco & Glazoué & Idaatcha & 20 \\
6 & Longbondjin & Glazoué & Mahi & 20 \\
7 & Montéwo & Savè & Tchabè & 20 \\
8 & Ouoghi & Savè & Tchabè /Idaatcha & 20 \\
9 & Thio & Glazoué & Mahi/ Idaatcha & 20 \\
\hline
\end{tabular}


Figure.1 Map Showing Surveyed Villages in Central Benin

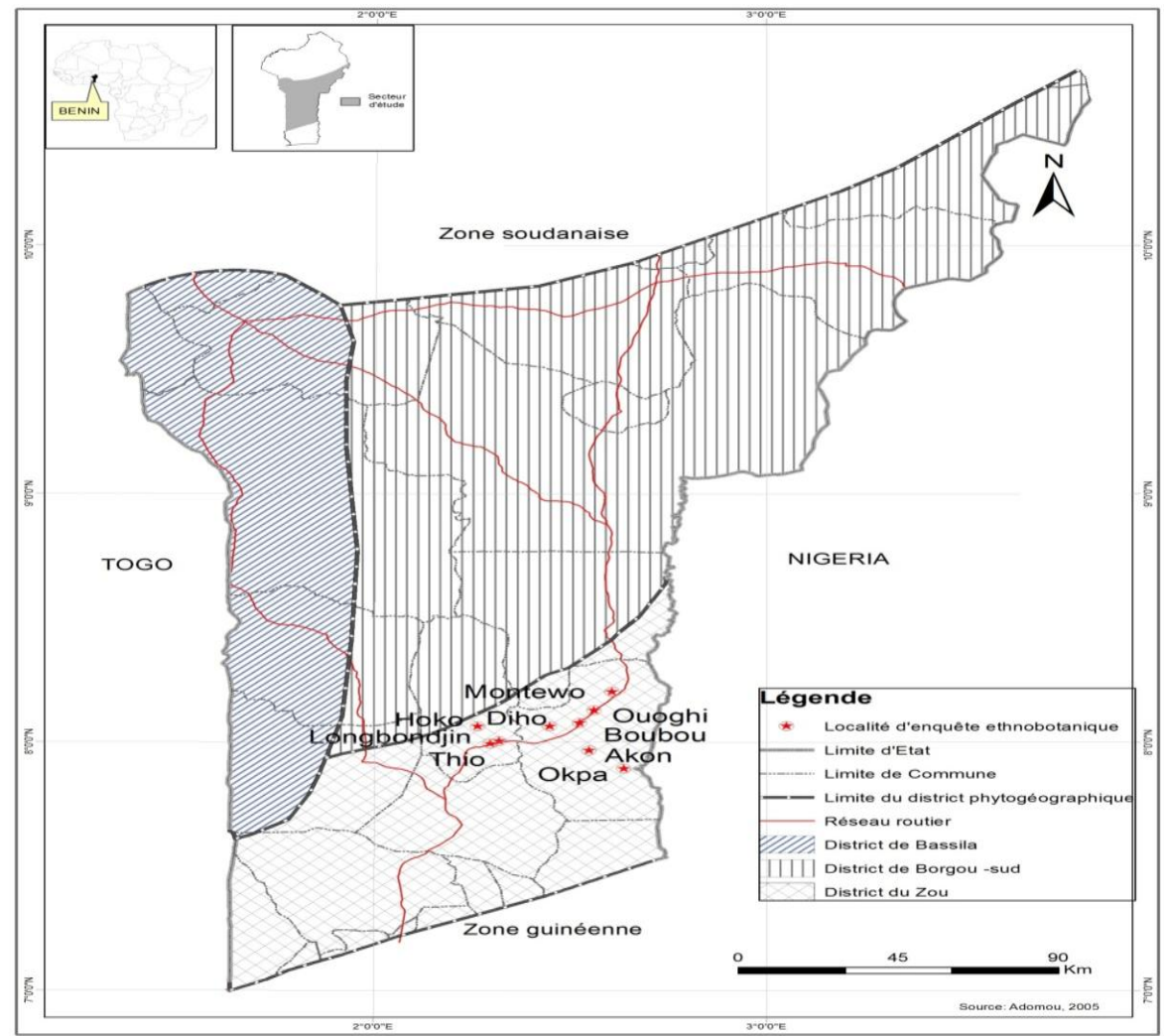

\section{Phytochemical Analysis}

The vegetable material consists of hypocotyls samplings collected from the study area. These hypocotyls were pulverized and used for the preparation of the ether extracts, methanol and aqueous obtained by successive extractions with solvents, according to the polarity level.The screening phytochemical is based on the reactions of colouring and precipitation of the principal chemical compounds groups contained in the different parts of the tree as described by Houghton and Raman (1998) and used by Dougnon et al. (2012) and Adjatin et al. (2013).

Alkaloids Determination: Alkaloids were identified through Mayer test which is an aqueous double potassium and mercury iodine solution. In acid solution and in presence of Mayer reagent, a reddish brown precipitation indicates the presence of alkaloids.

Polyphenolic Compounds Determination:

In an erlenmeyer, $5 \mathrm{~g}$ of powder to which $100 \mathrm{ml}$ of boiled water was added.The mixture was left for 15 minutes with continuous agitation, and then filtered. This filtrate divided into many portions will be used for research of the gallic and catechictannins, the flavonoids, the anthocyanins and leucoanthocyanes.

Tannins: With a portion of the filtrate, a proportion of to $1 \%$ ferric chloride was added. The presence of the tannins is related to the different colour observed which vary from blue, green or black.For the research of the catechics tannins, to $30 \mathrm{ml}$ of the filtrate, $15 \mathrm{ml}$ of Stiasny reagent was added. The appearance of a pink precipitate indicates the presence of the catechic tannins. Gallic 
tannins were assessed by recovery of the filtrate with $1 \%$ of ferric chloride.

Flavonoid: To $5 \mathrm{ml}$ of the previous filtrate, $5 \mathrm{ml}$ of hydrochloric alcohol and magnesium powder were added. The appearance of yellow or orange colour indicates the presence of flavonoids

Anthocyanins: To determine the presence of anthocyanins, hydrochloric acid at 5\% was added to $1 \mathrm{ml}$ of the filtrate. The solution was then mixture and ammonia solution was added. The results were analyzed by the presence of red colouring which is accentuated and transferred with blue-purplish or greenish.

Leucoanthocyanes: $5 \mathrm{ml}$ of hydrochloric alcohol was added to $5 \mathrm{ml}$ of the filtrate. The mixture is heated for 15 minutes at $90 \mathrm{C}$ with the Marie bath. Red colouration cherry or purplish indicated the presence of leucoanthocyanin.

Quinone Derivatives Determination: Quinone derivatives were assessed with Born-Trager reaction which is known as colouration reaction. A volume of $20 \mathrm{ml}$ of chloroform was added to a mixture of $2 \mathrm{ml}$ of $\mathrm{HCl}$ and $2 \mathrm{~g}$ of powder.After mixing, $5 \mathrm{ml}$ of ammonia was then added to the previous mixture.Pink or red color indicates a positive reaction.

Saponins Determination: The saponins were highlighted by the foam index which is the extent of dilution of one aqueous of the powder or drug.Indeed, the formation of a foam height higher stable and persistent than $1 \mathrm{~cm}$ indicates the presence of saponins.

Triterpenoids and Steroids Determination: The triterpenoids were identified by the test of the acetic acid with a mixture of acetic anhydride and acid sulphuric. The appearance of a violet, blue or green color related the presence of steroids.

\section{Cyanogenic Derivatives Determination}

The cyanogenic compounds were identified through picric test of acid. $2 \mathrm{~g}$ of the powder was added in $15 \mathrm{ml}$ of distilled water contained in anerlenmeyer. The mixture was immediately covered with paper soaked with picric acid. The mixture was then heated and brown colour indicating the presence of the hydrocyanic acid.

\section{Mucilage Determination}

$1 \mathrm{ml}$ of the extract was added to $10 \%$ is introduced into a test tube on which $5 \mathrm{ml}$ of alcohol was then added. The appearance of a flocculent precipitate indicates the presence of mucilage after ten minutes.

\section{Coumarins Determination}

Coumarins were highlighted with ether and ammonia.To $20 \mathrm{ml}$ of ether $1 \mathrm{~g}$ of crush powder of the hypocotyls was added to 0.5 $\mathrm{ml}$ of ammonia (25\%). Coumarins were then read an intense fluorescence under UV at $365 \mathrm{Nm}$.

\section{Reducing Compound}

The reducing compounds were assessed with Fehling's solution. 5g powder was diluted in $50 \mathrm{ml}$ of distilled water. Sharp red precipitate indicates the presence of reducing compounds.

\section{Anthracene Derivatives}

They are two types of anthracene derivatives: Free anthracene and the anthracene compounds (Anthracene combined O-heterosides and combined to 
anthracniques C-heterosi des).These anthracene derivatives were identified with chloroform and ammonia solution. At the end, light red colour observed suggested the presence of anthracenes.

\section{Heterosides Cardiotonics}

The reagents of Baljet, Kedde and Raymond-Marthoud were used to determine the heterosides. The presence of the heterosides was assessed base on the different colour observed (orange, redpurplished or violet).

\section{Results and Discussion}

\section{Medicinal and Medico-magic Usages of Borassus aethiopum}

The principal usages of $B$. aethiopium were medicinal and for food purpose. All the different organs of this tree such as the nucleus, the root and the hypocotyls were used in the treatment of some diseases (Table 1). In a total, the study revealed that $B$. aethiopum treat five (5) different diseases and the indigenous knowledge relative to the uses of the organs vary from one village to another. Concerning the nucleus, $48 \%$ of the surveyed use it to fortify the new born, regarding the root of $B$. aethiopum were it was cited by only $10 \%$ of responses whose used it to treat malaria, $30 \%$ of the surveyed highlighted the it can be used to fortify the pregnant lady. Also, $60 \%$ of the surveyed use the root to attenuate or to minimize the menstrual pain with the young lady and to treat sexual weakness. Relatives to the hypocotyls, $100 \%$ of the surveyed apart for the food matter it used to treat sexual weakness. Sexual weakness is the like disease treated by many organ of the plant includes the root and hypocotyls. In general, infusion and the soaking were identified as the most method and differ from one organ to another. Regarding the hypocotyls, to treat the sexual weakness it has been soaking only in the local alcohol call "sodabi" or with some other product. Screening physicochemical will allow us to bring out chemical group responsible for medicinal properties.

Concerning medico-magic usage, the utilization and the perception vary from one socio ethnic group to another and from one survey to another. (Figure 2) Individual surveyed revealed the $B$. aethiopum is considered as tree totem ( $57 \%$ of responses) or fetish tree (25\% of responses). According to $11 \%$ of responses, B. aethiopum tree is used for poison purpose and only $7 \%$ of the survey revealed that $B$. aethiopum is used for food purpose and any totem were not in relation with it. In general in Savé, $B$ aethiopum is used for poison purpose and is considered as blasted tree. In this ethnic group, $B$ aethiopum is considered as totem tree and is considered as fetish of the village. The populations surround the tree with stones animals were sacrificed to dismiss the bad sprits after consultation of an oracle. For that, population are avoiding bringing any parts of tree in the village. But in Glazoué district inhabited by Mahi and Idaatcha, the tree does not have any totem significance but considered as "tree fetish" because it is a perennial woody species having a late flowering and consequently produced fruits after several years.

\section{Phytochemical Screening}

The results of the screening phytochimic carried out on the extracts of hypocotyles of $B$ aethiopum revealed the presence of catechicand gallictannins, anthocyanins, leuco-anthocyanes, mucilage, saponins, combined anthracene O-heterosides, combined anthracene C-heterosides, steroids and coumarins (Table 3).However, the test 
revealed the absence of many compound such as alkaloids, flavonoids, cyanogenic derivatives, reducing compounds, free anthracene derivates, heterosides cardiotonics, triterpenoids, quinone derivate
(Table 2). Consequently the medicinal properties allotted to this species are due to the presence of the identified phytochimic groups.

Table.2 Diseases Treated by the Root and Hypocotyls of B. aethiopum in SavèetGlazoué District

\begin{tabular}{llcl}
\hline Organs & Domain of uses & Frequency (\%) & Usage mode \\
\hline Nucleus & Strength the new born & 48 & Infusion \\
\hline Roots & Malaria & 10 & Infusion of the roots in water \\
\cline { 2 - 4 } & Strength pregnant lady & 30 & \\
\cline { 2 - 4 } & Painful menstrual & 60 & $\begin{array}{l}\text { Grind the root of } \text { B. aethiopum } \\
\text { in the water only or associated } \\
\text { with others plants }\end{array}$ \\
\hline Sexual weakness & 60 & $\begin{array}{l}\text { Grind the hypocotyls of } B . \\
\text { aethiopum in the local alcohol } \\
\text { only or associated with others } \\
\text { plants }\end{array}$ \\
\hline
\end{tabular}

Table.3 Screening Phytochemical of the Hypocotyls

\begin{tabular}{lc}
\hline Chemicals compounds & Results \\
\hline Alkaloids & - \\
CathechicTannins & + \\
Gallictannins & ++ \\
Flavonoids & - \\
Anthocyanins & + \\
Leucoanthocyanes & + \\
Mucilage & ++ \\
Saponins & + \\
Cyanogenic derivatives & - \\
Reducing compounds & - \\
Free anthracenicderivates & - \\
CombinedAnthracenics O-heterosides & + \\
Combined Anthracenics C-heterosides & ++ \\
Heterosidescardiotonics & - \\
Triterpenoids & - \\
Steroids & + \\
Coumarins & + \\
Quinone derivatives & - \\
\hline NB: $(++)=$ Much; $(+)=$ Presence; $(-)=$ Absent $++l-=$ traces &
\end{tabular}


Figure.2 Perception of the B. aethiopum usage in the Study Area

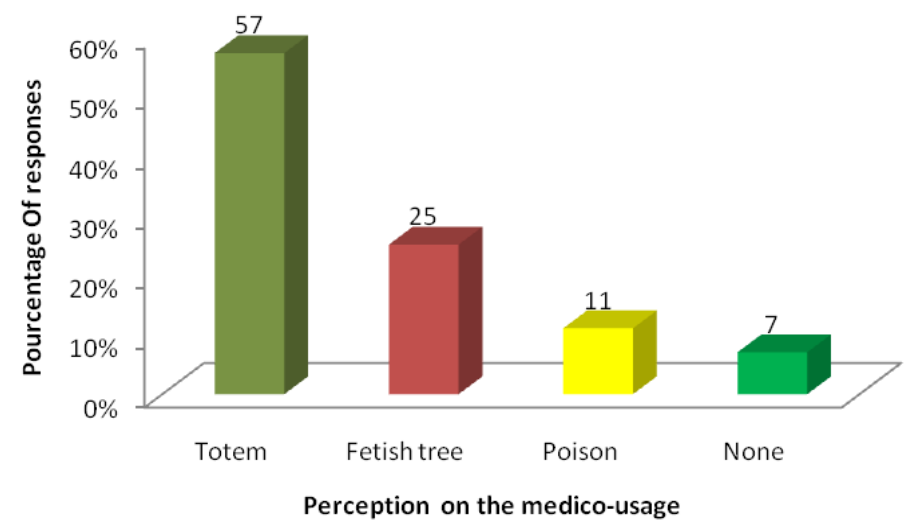

Borassus aethiopum is a tropical plant used as well for food purpose and also used in traditional medicinal (Adjou, 2006; Kansolé, 2009;Gbesso et al., 2013).This species also has medico-magicaluses that have been reported in the cultural area Tchabè. The medico-magical use of Cleome gynandra and Cleome viscosa was reported by Ahouansikpo et al. (2016) who showed that sauce of C.gynandra or C. viscosa eaten regularly would give longevity while their leaves harvested, dried and burned as incense move away evil spirits. This study showed the different part (cores, roots and hypocotyles) of $B$. aethiopum have been used in treatment of many diseases where eight were recorded in the study area among sexual weakness treated as well with the roots as with hypocotyles Moreover, among the different parts of B aethiopum, the hypocotyles constitute the most significant part which is consumed by the populations (95\% of responses) followed by the fruits (5\% of responses) (Gbesso et al., 2012).This high level of the consumption explains the interest of hypocotyles in the food but especially in the traditional medicine. These results are similar to those reported by Hessou, (2011) and Yaméogo, (2007) who highlighted the multiple usages of the of $B$ aethiopumin Benin also in Burkina-Faso. According to Akinniyietal, (2000), the young germinating shot of the seedling called Muruchi in Hausa is only known in Northern of Nigeria and peoples consume it as food and also for aphrodisiac matter or purposes. Another ethnobotanical study showed that certain part of the plant as the roots of Carica papaya are used out of herb tea because of their properties aphrodisiacs (Grenand et al., 2004). In the same way, different part Manniophyton fulvum and Flacourtia flavescens are used to treat the sexual weaknesses (Agbaire et al., 2012; Agassounon et al., 2012). Thus the extracts of the vegetable bodies are used in the traditional pharmacopeia to prevent or to treat the sexual dysfunction which was regarded as a psychological evil (Mormont, 1983) is currently perceived as a disease having an organic cause, mainly vascular (Garden, 2001). Several work showed that the presence of the chemical compounds in the vegetable confer pharmacological properties to them which would prove the use of these plants for various ends therapeutic (Agassounon et al., 2012; Dougnon et al., 2012; Adjatin et al., 2013).

Phytochemical screening conducted on the 
hypocotyles extracts revealed the presence of high chemical groups such as of catechic and gallic tannins, anthocyanins, leucoanthocyanes, mucilage, saponins, combined anthracene O-heterosides, combined anthracene C-heterosides, steroids and coumarins. These different compounds found in the plant have different pharmacological properties which vary for one group chemical to another. Tannins are known to have astringent properties; the presence of tannins in the hypocotyls of $B$ aethiopum edge supports its usage to treat and heal haemorrhoids which constitute the principal cause of sexual dysfunction (Andzouana and Mombouli, 2012).Tannins are phenolic compounds consider as free antioxidants radical scavengers (Adedapo et al., 2013).In general, plants with phenols are medicinal plants with majority of secondary metabolites include the phenolic acids, coumarins, flavonoids, anthocyanins and tannins responsible for medicinal properties such as disinfectant, analgesics, antiinflammatory, antidiuretic, immuno-tensor, antioxidant, analgesic, and antimalarial properties (Lay et al.,2010; MpondoMpondo et al., 2012). Anthocyanins are natural pigments usually in plant leaves, petals and fruits and generally have antioxidant activities and play a beneficial role in human health, in particular in the field of the cardiovascular risks and attacks (Oszmianski et al., 2007; Muanda, 2011).In general, mucilage, are known for their analgesics and disinfectants properties it also used dermatological. Coumarins are antibacterial, fungicides, laxatives, antitumor, urinary disinfectants, etc. The anthracene derivatives and saponosides have a large role in spectrum (Authors).The presence of all these chemical groups could explain well the aphrodisiac activity of $B$. aethiopum hypocotyles.

Spectrophotometric showed that B. aethiopum hypocotyls contain saponins. Saponins or saponosides are compounds produced naturally by some plants. According to Bruneton, (1999) and Békro (2007), saponins produce high spermicidal and are used for the manufacture creams for the vaginal application.S teroidal compounds are used to reduce cholesterol levels in human body, activate immune system, enhance memory and involved in tumour treatment (Sing et al, 2010; Veena et al., 2011). Steroids compounds found in hypocotyls is likely responsible for the aphrodisiac properties (Visweswari et al., 2013). Due to the different compounds found in $B$ aethiopum, this plantcould be used as raw materials for pharmaceutical industries as it is the case of Garcinia cola (Okwu, 2005).These results are similar to those obtained by Bourobou et al. (2014) on Tabernanthe iboga which is largely used by the populations for its medico-magic and medicinal properties like aphrodisiac.

In conclusion, the ethnobotanical study carries out in Savè and in Glazoué disctricts showed that $B$ aethiopum is used as well as for food and also to treat sexual weakness. The phytochemical screening on the hypocotyls extracts of $B$ aethiopum proved in addition compounds which could be probably responsible for aphrodisiac activity. These results lead us to suggest that $B$ aethiopum hypocotyls could be used to manufacture some drugs to treat the sexual weakness. However, more studies like in vivo evaluation are necessary to evaluate the effectiveness of hypocotyls as well as the toxicity test on larvae shrimp to evaluate possible toxicity of the different part of Borassus aethiopum especially the hypocotyls the most part consume.

\section{Acknowledgment}

We thank CUD (Commission Universitaire 
pour le Dévelopement) from Belgium for its financial contribution for this work. Also ours grateful to the local population of these two districts who provided useful information for us during ours survey.

\section{References}

Adamu, B., Isah, Emmanuel, O., Olorunsola, Yohanna, E., Zaman. 2012. Physicochemical properties of Borassus aethiopum. Starch Asian J. Pharm. Clin. Res., 4(3): 132-134.

Adedapo, A., Adewuyi, T., Sofidiya, M. 2013. Phytochemistry, antiinflammatory and analgesic activities of the aqueous leaf extract of Lagenariabreviflora (Cucurbitaceae) in laboratory animals. Int. J. Trop. Biol., 61(1): 281-290.

Adjanohoun, E.J. 1995. La biodiversité tropicale face au développement des industries pharmaceutiques. Med. Trad. Afr., 5: 3-18.

Adjatin, A., Dansi, A., Eze, C.S., Assogba, P., Dossou-Aminon, I., Akpagana, K., Akoègninou, A., Sanni, A. 2012. Ethnobotanical investigation and diversity of Gbolo [Crassocephalum rubens (Juss. ex Jacq.) S. Moore and C. crepidioides (Benth.) S. Moore, a traditional leafy vegetable under domestication in Benin. Genetic Res. Crop Evolution, 59(8): 1867-1881.

Adjatin, A., Dansi, A., Badoussi, E., Loko, Y.L., Dansi, M., Azokpota, P., Gbaguidi, F., Ahissou, H., Akoègninou, A., Akpagana, K., Sanni, A. 2013b. Phytochemical screening and toxicity studies of Crassocephalum rubens(Juss. ex Jacq.) S. Moore and Crassocephalum crepidioides (Benth.) S. Mooreconsumed as vegetable in Benin. Int. J. Curr. Microbiol. App. Sci., 2(8): 1-13.
Adjou, E. 2006. Caractérisation physicochimique et microbiologique du jus de la pulpe du fruit de rônier (Borassus aethiopumMart.), Mémoire de Maîtrise. Faculté des Sciences et Techniques, Université d'Abomey-Calavi, 76 p.

Agbaire, P.O., Emudainohwo, J.O.T., Peretiemo-Clarke, B.O. 2013. Phytochemical screening and toxicity studies on the leaves ofManniophytonfulvum. Int. J. Pl. Ani. Environ. Sci., 3(1): 1-6.

AgassounonDjikpoTchibozo, M., Savadogo, A.D.S., Karou, F., Toukourou, C., Souza. 2012. Connaissances endogènes et études phytochimiques de Flacourtiaflavescens Wild. (Flacourtiaindica Burn F. Merr.) Tropicultura, 30(1): 3-8.

Ahouansinkpo, E., Atanasso, J., Dansi, A., Adjatin, A., OrobiyiAzize, Sanni, A. 2016. Ethnobotany, Phytochemical Screening and Toxicity Risk of Cleome gynandra and Cleome viscosa, two traditional leafy vegetables vonsumed in Benin. Int. J. Curr. Microbiol. App. Sci., 5(2): 813-829.

Akinniyi, J.A., Waziri, M., Usman, H.S. 2000. Study of the Androgen contents ofBorassus aethiopum mart. Unimaid Res. Report, pp. 20-28.

Akoègninou, A., Adjakidje, V., Essou, J.P., Sinsin, B., Yedomonhan, H., Van Der Brug, W.J., et, Van Der Maesen, L.J.G. 2006. Flore analytique du Bénin. Universitéd'Abomey-Calavi, Cotonou, Bénin, 1034 p.

Ali, A., Alhadji, D., Tchiegang, C.. Saïdou, C. 2010. Physico-chemical properties of palmyra palm (Borassus aethiopum Mart.) fruits from Northern. Afri. J. Food Sci., 4(3): 115-119.

Andzouana, M., Mombouli, J.B. 2012. 
Assessment of the Chemical and Phytochemical Constituents of the Leaves of a Wild Vegetable Ochthocharisdicellandroides (Gilg). Pakistan J. Nutrition, 11(1): 94-99.

Azokpota, P., Gbaguidi, M.D.D., Montcho, D., Sagbo, S.Y.F. 2012. Formulation de farine et couscous à base de racines d'hypocotyles de rônier (Borassus aethiopumMart) d'écologie béninoise, Actes $d u$ troisième colloque de l'UAC, Vol III, pp. 145-166.

Békro, Y.A., Békro, J.A.M., Boua, B.B., Trabi, F., et. Éhilé, E.E. 2007. Étude ethnobotanique et screening phytochimique de Caesalpiniabenthamiana. Sci. Nat., 4(2): 217-225.

Bonetti Emmanuelle, 2007. L'impuissance et son traitement: comment le médicament modifie la définition de la maladie. Éditions de l'Ehess Annales. Histoire, Sciences Sociales, pages 327-351.

Boua, B.B. 2005. Études des effets pharmacodynamiques de Mezoneuronbenthamianum

(Caesalpiniaceae), une plante entrant dans le traitement de l'impuissance sexuelle. Mémoire de DEA, Université d'Abidjan Cocody. 59 pp.

Bruneton, J. 1999. Parmacognosie Phytochimie- Plantes médicinales, 3e Édition. Éditions Tec \&Doc et médicales internationales. $F$ 94234Cachan, Paris (France); 1120 p.

Cassou, J., Depommier, D. 1997. Le parc à rônier (Borassus aethiopum Mart.) de Wolokonto dans le Sud-Ouest du Burkina-Faso: Structure, dynamique et usages de la rôneraie. In: Anon. Réunion tripartite sur l'agroforesterie.Réunion tripartite sur l'agroforesterie. 7, 1997-0603/1997-
06-05, (Sikasso,Burkina) pp.1-13.

Cassou, J. 1996. Le parc à rôniers (Borassus aethiopum Mart) de Wolonkoto dans le sud-ouest du Burkina Faso: structure, dynamique et usages de la rôneraie, $103 \mathrm{pp}$.

Dougnon, T.V., Bankolé, H.S., Johnson, R.S., Klotoé, J.R., Fernand, G.D., Assogba, G.F. 2012. Phytochemical Screening, Nutritional and Toxicological Analyses of Leaves and Fruits of Solanum macrocarponLinn (Solanaceae) in Cotonou (Benin). Food Nutr. Sci., 3: 1595-1603.

Gbesso, F., Akouehou, G., Tente, B., et. Akoègninou, A. 2013. Aspects technico-économiques de la transformation de Borassus aethiopumMart (Arecaceae) au Centre-Benin». Afrique-Science, 9 (1): 159-173.

Gbesso, F., Lougbegnon, O.T., Tente, B., et. Akoègninou, A. 2012. Charactérisation écologique et morpho-structurale des populations de Borassus aethiopumMart (Arecaceae) dans les communes de Savé et de Glazoué. Les cahiers de CBRST 1 (2012): 257-270.

Grenand Pierre, Christian Moretti, Henri Jacquemin, Marie-Françoise Prevost. 2004. Famille Caricaceae. In Pharmacopées traditionnelles en Guyane. Paris: IRD éditions, pp. 290-292.

Hessou, A.F. 2011. Importance socioculturelle et statut de conservation de Borassus aethiopum Mart. (Arecaceae) dans la Réserve de BiosphèreTransfrontalière du $\mathrm{W} d u$ Niger et les terroirs riverains au Bénin. Mémoire de DESS RESBIO/FSA/UAC, 57 p.

Houankoun, E. 2003. Importance socioéconomique du rônier (Borassus 
aethiopum): différents usages et commercialisation de quelques sousproduits au Bénin. Mémoire DEA/UAC, $99 \mathrm{p}$.

Houghton, P.J., et. Raman, A. 1998. Laboratory Handbook for the Fractionation of Natural Extracts, Chapman and Hall, New York, pp. 130-207. doi:10.1007/978-1-46155809-5

Jardin, A. 2001. Facilitateurs, inducteurs de l'érection... ou aphrodisiaques ", in P. Queneau, F.Giuliano et A. Jardin, Progrès thérapeutiques: la médicalisation de la sexualité en question, Montrouge, John LibbeyEurotext, pp. 115-119.

Kansolé, M.R. 2010. Valorisation de quelques produits dérivés de Borassus aethiopum Mart. Dans le bassin versant de la Kompienga (Burkina faso). Mémoire DESS, Uni. Ouagadougou, $75 \mathrm{p}$.

Mormont, C. 1983. Théories et traitements psychologiques de l'impuissance érectile », Thèse de Doctorat en psychologie, Université de Liège.

MpondoMpondo, E., Dibong, S.D., Yemeda, C.F.L., Prisco, R.J., Ngoye, A. 2012. Les plantes à phenols utilisées par les populations de la ville de Douala. $J$. Ani. Pl. Sci., 15(1): 2083-2098..

MpondoMpondo, Emmanuel, Didier Siegfried Dibong, Christelle Flora, LadohYemeda, Richard Jules Priso, Alfred Ngoye. 2012. Les plantes à phénols utilisées par les populations de la ville de Douala. J. Ani. Pl. Sci., 15(1): 2083-2098.

Muanda, F., Kone, D., Dicko, A., Soulimani, R., Younos, C. 2011. Phytochemical composition and Antioxidant Capacity of Three Malian Medicinal Plant Parts.Evid-Based. Compl.Alt. Med., 8 p.

Okwu, D.E. 2005. Phytochemicals, vitamins and mineral contents of two Nigeria medicinal plants. Int. J. Mol. Med. Adv. Sci., 1(4): 375-381.

Oszmianski, J., Wojdylo, A., LamerZarawska, E., Swiader, K. 2007. Antioxidant tannins from Rosaceae plant roots. Food Chem., 100(2): 579-83.

Pousset, J.L. 1992. Plantes médicinales africaines. Possibilités de développement (Tom II). Agence de Coopération Culturelle etTechnique. Ellipses, Paris (France), 159 p.

Price, L., et. Ousmane, B.G. 1999. Les communautés locales et la gestion des rôneraies de Dallol Maouri et du fleuve Niger: l'exemple d'une dynamique de développement durable au Niger. http://www.cdr.Dk/sscafrica/p802.tn-html, $15 \mathrm{p}$.

Sakande, J., Nacoulma, O.G., Nikiema, J.B., Lompo, M., Bassene, E., Guissou, I.P. 2004. Etude de l'effet antipyrétique d'extraits des inflorescences mâles du ronierBorassus athiopumMart. (Arecaceae), in revue Médicined'Afrique Noir, Tome $51, \mathrm{~N}^{\circ} 5,280-282 \mathrm{p}$.

Sandhya, B., Thomas, S., Isabel, W., Shenbagarathaï, R. 2006. Ethnomedicinal plants used by the valaiyan community of Pairanmalai Hills (Reserved Forest), Tamilnadu, India-APilot Study. Afri. J. Traditional Complementary and Alternative Med., (1): 101114.

Singh, A., Duggal, S., Singh, H., Singh, J., Katekhaye, S. 2010. Withanolides: Phytoconstituents with significant pharmacological activities. Int. J. Green Pharm., 4:229-237.

Visweswari, G., Christopher, R., Rajendra, W. 2013. Phytochemical screening 
of active secondary metabolites present in Withaniasomnifera root: role in traditional medicine. Int. $J$. Pharm. Sci. Res., 4(7): 2770-2776.

Waziri, M., Akinniyi, J.A., Salako, A.A. 2010. Toxicity of Acetone Extract of Muruchi, the Shoot of Borassus aethiopum Mart. Euro. J. Sci. Res., 41(1): 6-12.

WHO. 2002. Traditional Medecines Strategy 2002-2005, Geneva, Switzerland.

Yaméogo, J. 2008. Contribution des parcs à Borassus akeassii au fonctionnement des systèmes de production dans le sud-ouest du Burkina-Faso, $181 \mathrm{p}$. Yaméogo, J., Ouédraogo, M., Bayala, J., Ouédraogo, B.M., et. Guinko, S. 2007. Uses and commercialization of Borassus akeassii Bayton, Ouédraogo, Guinko nonwoodtimberproducts in SouthWestern Burkina Faso, West Africa, Biotechnologie, Agronomie, Société et Environnement, 12 p.

Zwenger, S., Basu, C. 2008. Plant terpenoids: applications and potentials. Biotechnol. Mol. Biol. Rev., 3: 001-007.

\section{How to cite this article:}

Florence Gbesso, Arlette Adjatin, Alexandre A. Dansi and Akpovi Akoegninou. 2016. Aphrodisiac Properties of Hypocotyls Extracts of Borassus aethiopum Mart (Arecaceae) Collected in Central of Benin Republic. Int.J.Curr.Microbiol.App.Sci. 5(3): 802-814. doi: http://dx.doi.org/10.20546/ijcmas.2016.503.093 